\title{
Study on Implicit Ideological and Political Education Theory and Reform in Higher Vocational Colleges
}

\author{
Yanling Zhang \\ Northeast Petroleum University at Qinhuangdao, Qinhuangdao, China \\ Email: w ddan@163.com \\ Received 26 January 2015; accepted 8 May 2015; published 13 May 2015 \\ Copyright (C) 2015 by author and Scientific Research Publishing Inc. \\ This work is licensed under the Creative Commons Attribution International License (CC BY). \\ http://creativecommons.org/licenses/by/4.0/ \\ (c) (7) Open Access
}

\begin{abstract}
The rapid development of higher vocational education in our country, to higher vocational ideological and political education work has brought serious challenges, researching the effectiveness of the ideological and political education work, improving the effect of education, higher vocational education is not only the objective need of development, is suspending in front of ideological and political education workers a key subject concerning theory and practice. Based on the method of recessive ideological and political education in higher vocational colleges in the field of the characteristics and development, the paper analyzes the current situation of ideological and political education, and puts forward the recessive ideological system of ideological and political education of college students in China.
\end{abstract}

\section{Keywords}

Explicit Education, Implicit Education, Implicit Course, The Method of Implicit Political and Ideological Education

\section{Introduction}

Computer majors mostly still adopt the traditional teaching mode, which is low effect. Under the new situation of ideological and political education in higher vocational colleges, the disadvantages of the traditional dominant education, the characteristics of higher vocational college students' physical and mental development and other various aspects are all factors on the needs of the higher vocational colleagues which must be paid attention to and strengthen the recessive ideological and political education of students. At the same time, the experience of the Chinese traditional moral education and the recessive education resource is widespread, and also streng- 
thening the recessive ideological and political education of higher vocational students provides a possible condition.

\section{Overview of the Implicit Ideological Education and Political Education}

\subsection{The Origin of the Implicit Ideological and Political Education}

At the beginning of the twentieth century, American educator Dewey, according to the theory and practice of his education, proposed to abolish the moral education course. He advocated carrying out moral education by letting children participate in the social life and solve various practical problems. In 1968, American scholar Jackson in his monograph "Life in Class" formally proposed the concept of "implicit course". Since then, the western social educators began to discuss the issue of implicit course. The principle of implicit education was introduced to the ideological and political education (Li, 2010).

\subsection{Characteristics of the Implicit Ideological and Political Education}

1) The implication in the education process

The implicit ideological and political education does not require college students to have the ideological and political classes, take corresponding examinations, get credits or meet other mandatory requirements. It hides the purpose and intent of education into college students' study and life, and guides the educatees to fit in the educational situation created by the educators naturally. Students would accept the edification and influence imperceptibly, so as to improve their ideological and moral quality.

2) Diversity of educational method

The implicit ideological and political education covers a lot of ground, with a lot of educational methods, such as campus environment, campus culture, interpersonal relationship in campus, the personality quality of educator, society activities, social practice and so on, which can meet the maximum needs of college students.

3) The effectiveness of educational results

The explicit ideological and political education often pursue to get effect instantly, but more haste, less speed. However, the implicit ideological and political education can achieve the qualitative change after going through a long time, which helps students form a stable, solid ideological quality and morality. The effect is more durable.

\section{The Present Situation of the Implicit Ideological and Political Education in Higher Vocational Colleges in China}

\subsection{Managers' Indifference to the Implicit Ideological and Political Education in Some Higher Vocational Colleges}

At present, many higher vocational colleges simply manage some daily affairs, and neglect the formulation and implementation of school rules and regulations upon college students' ideological and political education. For the method of implicit political and ideological education, they stay in the concept cognition level and still not get rid of the traditional education method in practice, and do not have the full excavation of the implicit ideological and political education in specialized course teaching process (Pan, 2013).

\subsection{The Short of Intensity of the Educational Effect in Higher Vocational Colleges}

From the results of ideological and political courses, such as Introduction to Mao Ze Dong Thought, Deng Xiaoping Theory and similar subjects, in higher vocational colleges, it is not difficult to find that students often get higher scores with less effort than other subjects. They think these subjects are easy to slip by. Therefore, they do not go to class and ask somebody answer for them in roll call. College students become inured to the unusual on the reciting phenomena only when the exams draw near. If things go on like this, one can imagine the situation of college students' ideological and moral level.

\subsection{Further Enhancement of Teachers' Quality in Higher Vocational Colleges}

The leading role of educators can not be ignored in the process of implicit ideological and political education. At present, the overall quality of the ideological and political education team is good. But there are very few teach- 
ers with low ideological and theoretical quality. Some teacher's acts even belie their words. They advocate morality but they are immoral; advocate disciples but they are not disciplined.

\section{The Construction of the Implicit Ideological and Political Education System in Higher Vocational Colleges}

It is a systematic engineering to construct the implicit ideological and political education in higher vocational colleges, which needs to be constructed from two aspects, software and hardware.

\subsection{Viewing the Construction of the Implicit Ideological and Political Education in Higher Vocational Colleges from the Perspective of Hardware}

1) Strengthening the construction of campus environment

Good environment can shape a good character. Apart from the practical value, the school building \& equipment, landscaping and various decorations have symbolic significance and the function of cultivation, such as the Weiming Lake in Peking University, Yuelu Academy in Hunan University and beautiful cherry blossom in Wuhan University. Therefore, the external environment of school is the basic factor of the implicit ideological and political education that can't be neglected (Zhang, 2009).

2) Strengthening the construction and management of campus rules and regulations

Rules and regulations are educational factors of the ideological and political education that can not be ignored in higher vocational colleges. As a nominative system, rules and regulations have the function of management and education, which could conduct moral standard and promote the formation of behavior in virtually. Rules and regulations embody humanization, legalization and scientific tendency of modern management, which will undoubtedly promote the students' sense of belonging to school, sense of identity, so as to push forward the process of socialization of college students and help they obey and internalize norms.

\subsection{Viewing the Construction of the Implicit Ideological and Political Education in Higher Vocational Colleges from the Perspective of Software}

1) The construction of the implicit ideological and political course

The implementation of the implicit course is conducive to the healthy development of moral quality of contemporary college students. The traditional moral education is concerned with knowledge rather than the individual spiritual pursuit. Therefore, students lack positive moral attitude and emotion experience in ideological and political education. For this reason, we cannot wake up, excite, and guide people to pursue virtue, which will inevitably cause a lack of self pursuit and self cultivation. The implementation of the implicit course is conducive to the cultivation of college students' moral behavior. The development of college students' social ability and personality are closely related to the formation of own moral behavior. Percolating through moral requirements, the implicit course elements form a vivid environment for moral education. All sorts of implicit course elements can play a major value in the cultivation of moral behavior. These elements percolate through moral requirements in a variety of environment through some special transmission mechanism, such as implication, public opinion, conformity and expectation, so that students feel this invisible requirement, generating potential psychological pressure and power, and restrain themselves, adjust and regulate their own behavior according to this kind of moral requirements consciously (Zhu, 2014). The implicit course would produce an overall impact on students, involving in cognition, emotion, faith and meaning, which prompt the perfection of their personality and the harmonious development, and form a lively optimistic and positive personality.

2) The construction of campus culture

The campus culture refers to the mental environment and cultural atmosphere unique to campus. It involves in the architectural design of campus, campus landscape, greening and beautifying and the materialized forms, as well as the tradition of the school, school spirit, style of study, interpersonal relationship, school rules and regulations (Han, 2006), and non explicit specified rules of conduct forming in the common activities among school members. Healthy and upward campus culture play the invisible role in molding the character of students, enlightening the mind of students and promoting comprehensive development of students.

a) In the construction of campus culture, we must first create a distinctive, healthy and upward campus culture. It shall seize students interests to carry out campus cultural activities and use forms and contents students are de- 
lighted to see and hear, such as holding a series of lectures, debates, knowledge contest, learning interest group and speech contest, to improve the knowledge structure of students, the ability of understanding, analyzing and solving problems in comparative identification and debate, and improve the ideological and political consciousness. It can expand students' field of vision, broaden their knowledge, promote the penetration of science and liberal arts and further improve their knowledge structure to hold "network security application" and "legal basis" knowledge lectures, and organize healthy and beneficial recreational and sports activities. The school should provide good entertainment for the faculty and carry out activities with leadership in an organized way to let the faculty feel the warmth from this big collectivity in all aspects. In the holidays or anniversaries, the school can carry out a cultural show, mass sports activities and contests, organize speech competition, solicit essay, and hold reading activities in order to celebrate the Arts Festival every year. The school also can organize the faculty to carry out activities in love, mobilize the staff to support the poor mountainous areas through donating clothes and freely provide people in poor areas with their knowledge and technique. Among the students, the school can hold youth volunteer activities and learn-from-Lei-Feng activities to give a little warmth to people who are in trouble and give the society a love dedication. The school with good conditions can carry out elective courses in literature and arts to improve the students' appreciation level on the masterpiece and the elegant music, which helps to purify the students' mind and sublime soul. The higher the students' quality and aesthetic level are, the more strongly students can resist the vulgar (Qin, 2005).

b) It is suggested to strengthen the construction of societies, enrich students' extracurricular cultural life, and activate campus academic air through operating student publications within society, running the campus window and blackboard newspaper in front of the building and in the corridor, and the school radio station well and organizing weekend salon and other activities. To a certain extent, these society activities could meet students' needs in politics, thought and the pursuit of life positively. In addition, students can experience thick cultural atmosphere personally in these activities. Consciously, they accept new knowledge and information from school or outside world, and then through processing they internalize these things as their own spiritual wealth and their own words and deeds. Consequently their ideological and political consciousness is improved, which will guide them to set up correct life guideposts.

c) We should reproduce the dormitory culture construction and bring the ideological and political education into the dormitory. The students' dormitory is their "first society" and "second family". Therefore, it has very important significance for the healthy growth of students to do a good job in the spiritual civilization in the dormitory. For this purpose, a daily schedule should be made for student's dormitory life first, and students are required to obey consciously. Secondly, a dormitory regulation should be made for students, and students are required to abide by the rules and disciplines of the school. Students should not only study hard, but also should maintain a tidy and clean dormitory environment, because a good environment will influence every student's character.

\subsection{The Improvement of the Teacher Quality}

The paper suggests to strengthen the construction of teachers' professional ethics and demeanor, and give play to the exemplary role of teachers. In the college campus, teachers contact with students face to face frequently, and they are the most influential person to students, so that teachers' demeanor, concept of value and dedicated attitude are very important to the formation of the students' world outlook, values and outlook on life. Teachers demonstrate morality, so they should have high moral level and quality. The construction of teachers' professional ethics and demeanor is directly related to the substantivity, ideological level and inspiration of the teaching content of the ideological and political education, and directly influences the effect of the ideological and political education. The teacher should affect the educatees with their own moral quality and knowledge power. If the teacher is not a person with good moral character, he/she is impossible to carry out the education of good moral quality to students. Teachers are desired to be knowledgeable, with independent thinking ability, a strong sense of social responsibility and health body. Only with these conditions, they have the qualification to face the next generation (Zhang, 2010).

In the college campus, teachers' every word and action, appearance and manner all convey their thoughts, personality, morality and emotion, and thus nurture and infect students' thought and emotion. In order to avoid the confrontation and separation of subject and object of the ideological and political education, teachers who teaching theory courses should improve their inner quality, manifest the rational charm of theory itself, but also 
pay attention to the affinity design of appearance and manner, and the building of optimistic and pleasant external image. Achieving that the moment students approach teacher, they may feel the close relationship between them. Therefore, the ideological and political education becomes easy to some extent.

\section{Conclusion}

Recessive ideological and political education method research in colleges and universities is a frontier subject. To improve the teaching quality of ideological and political education, and to enrich the ideological and political education method system are of important significance. The recessive thought political education method can be accepted by someone unconsciously, in the form of guiding educatee to obtain world outlook, the outlook on life, values, education, so as to realize the education of ideological and political education target method. Especially since the modern times, the unconscious reception theory, the theory of hidden curriculum, the ideological and political education methodology, the development of the theory of psychology, pedagogy, and further in-depth research build efficient recessive thought political education method system and provide the theory basis. In comparison with other methods, the recessive thought political education method has assimilation cognition, constructing psychological advantage, edify sentiment, and standardized behavior. Ideological and political education should give full play to the role of the recessive ideological and political education, stimulating and optimizing various recessive thought political education resources, constructing the recessive thought political education method system. To improve the efficiency of the ideological and political education is of great significance.

\section{References}

Han, J. (2006). Development and Utilization of Implicit Education Resources in the Ideological and Political Course in Higher Vocational Colleges. Journal of Jilin College of Commerce, 1.

Li, T. (2010). Research on the Methods of Implicit Ideological and Political Education in Colleges and Universities. Dalian: Master's Thesis of Dalian University of Technology.

Pan, W., \& Li, Y. W. (2013). Thinking about Strengthening the Recessive Ideological and Political Education in Colleges and Universities. Career and Education, 33.

Qin, Y. F. (2005). Initial Exploration on Design and Development of Implicit Moral Education Course in Higher Vocational Colleges. Journal of Ideological and Theoretical Education, 12.

Zhang, T. (2009). The Inner Mechanism of the Theory of the Recessive Ideological and Political Education in Colleges and Universities. Heilongjiang Province Higher Education Research, 8.

Zhang, X. L. (2010). Discussion and Analysis on Implicit Ideological and Political Education in Colleges and Universities. Shanghai: Master's Thesis of East China Normal University.

Zhu, J., \& Jiang, M. Q. (2014). The Necessity and Feasibility of Recessive Ideological and Political Education in Higher Vocational Colleges. The Contemporary Education Theory and Practice, 7. 